\title{
Strategies on Developing Human Resource Performance for the Librarians and Archivist in West Java Province Indonesia
}

\author{
Nefi Aris Ambar Asmara*, Ricky Adi Putranto \\ National Institute for Public Administration \\ Bandung, Indonesia \\ *nefi_asmara@yahoo.com
}

\begin{abstract}
This research aims understanding and finding the strategies for the development of human resource performance for Librarians and Archivist (L/A) employing by the Regional Library and Archive Office of West Java Province Indonesia. Using a descriptive qualitative approach, data in this research was collected through observations and in-depth interviews as well as documentary compilations with the informants working in three respective offices. Data was then presented and analyzed by using the Strength, Weakness, Opportunity, Threat (SWOT) Analysis. The analysis results reveals that, in regard to human resource, there are several strengths with the presence of adequate quantity and quality of librarians being one of them. While the human resource weakness includes the age of many librarians approaching the retirement. From the opportunity perspective, the involvement of literacy volunteers is the biggest opportunity. While the threat comes from the rapid technology advancement which demands human resources to learn and adapt faster, which cannot be easily done by many employees. In respect to the SWOT analysis, there are several recommended strategies including the development performance through the training for professional Librarians and Archivists officers, recruiting new Librarians and Archivists A officers, building technological culture in the libraries, and strengthening the partnership between the offices and volunteers.
\end{abstract}

Keywords-strategic human resource development performance, professional librarians and archivist, Indonesia

\section{INTRODUCTION}

Librarians and Archivists in the West Java are expected to carry out their main duties and functions so that the Regional Library and Archive Office of West Java Province's Vision and Mission can be achieved. The results of observations show that there are difficulties in achieving the vision and mission due to unreached performance targets from the points of view (1) allowance, (2) the educational qualifications, (3) the compatibility between allowances with the duties and functions. Therefore, there are four objectives that must be achieved in this study, namely (a) to describe the level of performance, (2) to describe mapping of Career Patterns, (3) to describe allowances provided with performance achievements.
There are four research objectives, namely (1) describing the related problems in order to improve performance, (2) describing the mapping of future career patterns, (3) describing the suitability of benefits provided with performance achievements and (4) future performance improvement strategies. which will come. The theoretical basis adopted is the SWOT analysis in Human Resources development from Zainal [1] using a three-stage conceptual model, namely Input, Process and Out Put. Input is the rules related to / underlying the functional position of librarian / archivist. A process consisting of knowledge, skills and attitude and Output. The main objectives of the results to be achieved in the study.

\section{RESEARCH Methodology}

This research adopts a qualitative descriptive approach and uses interview, observation and document study techniques. Some of the instruments used were interview guidelines, observation guidelines, document lists and recording devices. Research informants came from four (4) research loci originating from: Locus in DISPUSIPDA Garut Regency, Locus in DISPUSIPDA West Java Province, BKPPD Garut Regency and BKPD West Java Province which are structural Eschelon II, III and IV officials, Librarian and Archivist Functional Officials from the lowest level to the highest functional level in the two (2) research loci. From the 4 research loci above. While the data analysis uses the stages and mechanisms of SWOT Analysis, according to Ranguti [2] with the following stages: Internal Environmental Analysis (ALI), External Environmental Analysis (ALE), Determination of Strategic Issues by weighting Skala: 1 to 4, Mapping in the Organizational Strength Field (Force Field Diagram / FFD).

\section{FINDINGS AND DISCUSSION}

From the whole process and stages of this research, the general findings are presented below (Table 1). 
TABLE I. SUMMARY OF ANALYSIS OF EXTERNAL FACTIOS (KAFE)

\begin{tabular}{|c|c|c|c|c|}
\hline No & $\begin{array}{c}\text { External Factors } \\
\text { Strategis }\end{array}$ & Value & Rating & $\begin{array}{l}\text { Score } \\
(\mathbf{B x R})\end{array}$ \\
\hline (I) & (2) & (3) & (4) & (5) \\
\hline \multicolumn{5}{|c|}{ Opportunities } \\
\hline 1. & $\begin{array}{l}\text { Position and strategic prospect } \\
\text { of Librarian and Archivist. }\end{array}$ & 0,20 & 4 & 0,80 \\
\hline 2. & $\begin{array}{l}\text { Encouraging existing civil } \\
\text { servants to become Librarian / } \\
\text { Archivist }\end{array}$ & 0,15 & 2 & 0,30 \\
\hline 3. & $\begin{array}{l}\text { Information technology's } \\
\text { growth }\end{array}$ & 0,05 & 2 & 0,10 \\
\hline 4. & $\begin{array}{l}\text { Availability of allowances as } \\
\text { an adequate Compensation. }\end{array}$ & 0,15 & 4 & 0,60 \\
\hline \multicolumn{2}{|c|}{ Opportunies } & 0,55 & & 1,80 \\
\hline \multicolumn{5}{|c|}{ Threaths } \\
\hline 1. & $\begin{array}{l}\text { There is competition of } \\
\text { Compensation Benefits } \\
\text { between non Librarians and } \\
\text { Archivists and Librarians and } \\
\text { Archivists }\end{array}$ & 0,10 & 4 & 0,40 \\
\hline 2. & $\begin{array}{l}\text { Lack of motivation and } \\
\text { support from the local HRD } \\
\text { office to promote Librarians } \\
\text { and Archivists positions. }\end{array}$ & 0,20 & 4 & 0,80 \\
\hline 3. & $\begin{array}{l}\text { Non the Librarian / } \\
\text { Archivist's position is more } \\
\text { "prestigious" than the } \\
\text { Librarian / Archivist. }\end{array}$ & 0,05 & 1 & 0,05 \\
\hline 4. & $\begin{array}{l}\text { The occurrence of a natural } \\
\text { disaster or disturbance. }\end{array}$ & 0,10 & 2 & 0,20 \\
\hline \multicolumn{2}{|c|}{ Threaths } & 0,45 & & 1,45 \\
\hline \multicolumn{2}{|c|}{ Total } & 1,00 & & \\
\hline
\end{tabular}

The next step is to compile the KAFI and KAFE matrices for quadrant analysis using the Cartesian diagram. KAFI is depicted on the horizontal $\mathrm{X}$ axis and KAFE is depicted on the vertical $\mathrm{Y}$ axis. Determination of the points on the Cartesian diagram is done in the following manner:

\section{A. Quadrant analysis of strategies for DISPUSIPDA in West} Java Province:

1) KAFI coordinate points are determined using the formula:

\section{Axis $X=$ (Score of Strengths - Score of Weaknesses $)$}$$
\underline{X=(1,20-2,00)=-0,80=-0,40}
$$

$$
22
$$

2) The coordinate of KAFE usedis as follow:

\section{$\underline{\text { Axis } \mathrm{Y}=(\text { Score Opportunities }- \text { Score of Threths })}$}

$$
\underline{Y}=(1,80-1,10)=0,70=0,35
$$

Thus, the coordinate between KAFI and KAFE is ($0,40 ; 0,35)$

Visual force field diagram organisation is in Figure 1 below:

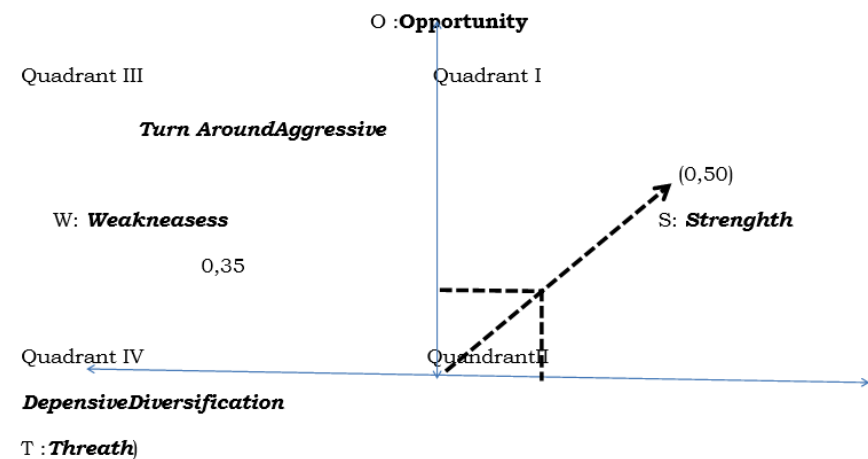

Fig. 1. Visual force field diagram organisation.

According to the results of the Figure 1 above, it is known that in the SWOT analysis above is possible, first the Regional Library and Archives Services of West Java Province, as a regulator agency, places its position as an institution or service that is assigned or has special authority related with the guidance and utilization of the competencies possessed by Librarian and Archivist Officers. Second, with the rewards in the form of Regional Performance Allowances which are very high compared to those obtained by Librarians and Archivists in other Provinces in Indonesia, this should be able to make Motivation in improving their performance. Third, apart from the Regional Performance Allowances, the Punishment element in the form of a demotion of Regional Performance Allowances which will have an impact on the acquisition Regional Performance Allowances, this is felt to be quite effective in continuing to spur their performance. Fourth, there is support from the Regional Civil Service Agency at both the City and Regency levels to continue to implement it by giving compulsory to take part in training that supports more competences as a Librarian and Archivist Functional Position. Finally, there is socialization from the leaders by providing motivation, opportunities and encouragement so that general functions under the human resource offices are interested and want to become Librarian and Archivist Functional Officials. This is because until now the number of human resources in the Regional Library and Archives Services of West Java Province is still very inadequate, especially if it is compared to the ratio of the number of Librarians who must provide services to the community. 


\section{CONCLUSION}

- Librarian / archivist's position allowance is not yet effective because its performance is not in accordance with the target,

- The suitability of educational qualifications for the position of librarian / archivist has not been achieved because the competence does not match the community by BKD,

- The suitability of the allowance and the target load of the task and the function is not appropriate because the allowances have been increased but the workload is not optimal.

\section{ACKNOWLEDGMENT}

The research could be completed thanks to the support of the Director of the Polytechnic of STIA and the Human Resources Offices and Library and Archive Offices of regencies of Garut, Purwakarta and Sukabumi and the provincial Human

Resources Office and Library and Archive Office of West Java.

\section{REFERENCES}

[1] V.R. Zainal, H.M. Ramly, T. Mutis and W. Arafah, Manajemen sumber daya manusia untuk perusahaan dari teori ke praktik. Jakarta: Prenada Media, 2019.

[2] F. Rangkuti, Marketing Analysis Made Easy. Jakarta: Gramedia Pustaka Utama, 2005. 